\title{
Flavonoids isolated from Tridax procumbens (TPF) inhibit osteoclasts differentiation and bone resorption
}

\author{
Md. Abdullah Al Mamun ${ }^{1 *}$, Kamrul Islam¹, Md. Jahangir Alam, Amina Khatun², M. Masihul Alam³, \\ Md. Abdul Alim Al-Bari ${ }^{4}$ and Md. Jahangir Alam ${ }^{1}$
}

\begin{abstract}
Background: The Tridax procumbens flavonoids (TPF), are well known for their medicinal properties among local natives. The TPF are traditionally used for dropsy, anaemia, arthritis, gout, asthma, ulcer, piles, and urinary problems. It also used in treating gastric problems, body pain, and rheumatic pains of joints. The TPF have been reported to increase osteogenic functioning in mesenchymal stem cells. However, their effects on osteoclastogenesis remain unclear. The TPF isolated from T. procumbens and investigated the effects of the TPF inhibit on osteoclast differentiation and bone resorption activities using primary osteoclastic cells. Osteoclast formation was assessed by counting the number of tartrate resistant acid phosphatase (TRAP) positive multinucleated cells and by measuring both TRAP activities.
\end{abstract}

Results: The TPF significantly suppressed the RANKL-induced differentiation of osteoclasts and the formation of pits in primary osteoclastic cells. The TPF also decreased the expression of mRNAs related to osteoclast differentiation, including Trap, Cathepsin K, Mmp-9, and Mmp-13 in primary osteoclastic cells. The treatment of primary osteoclastic cells with the TPF decreased Cathepsin K, Mmp-9, and Mmp-13 proteins expression in primary osteoclastic cells.

Conclusion: These results indicated that TPF inhibit osteoclastogenesis and pits formation activities. Our results suggest that the TPF could be a potential anti-bone resorptic agent to treat patients with bone loss-associated diseases such as osteoporosis.

Keywords: Bone resorption, Osteoclast differentiation, Pit formation, TRAP positive cells

\section{Background}

The human bone is a highly dynamic organ that maintains its homeostasis through a delicate balance between the bone-forming osteoblasts and the bone-eroding osteoclasts $[1,2]$. The dynamic balance between these two cells types results in bone remodeling. Osteoclasts are multinucleated giant cells that differentiated from cells of hematopoietic monocyte macrophage linage under the presence of two critical factors: the receptor activator of NF-kB ligand (RANKL) and the macrophage monocyte colony-stimulating factor (M-CSF) [2]. Both factors

\footnotetext{
*Correspondence: mssohel@yahoo.com

1 Department of Genetic Engineering and Biotechnology, Shahjalal

University of Science and Technology, Sylhet 3114, Bangladesh

Full list of author information is available at the end of the article
}

are produced by osteoblasts or stromal cells [2]. Osteoclasts, which are essential in bone homeostasis, play a key role in the development of osteoporosis, inflammatory arthritis, and rheumatoid arthritis (RA), osteoporosis, or low bone mineral density (BMD), is a important risk factor for fracture in older women [3]. Progressive bone destruction in RA involves the abnormal activation of osteoclasts, which is due to interactions with synovial fibroblasts and helper T cells that express the RANKL [4, 5]. Traditional medicine is an important source of potentially useful new compounds for the development of therapeutic agents [6]. Emergence of pathogenic microorganisms that are resistant or multi-resistant to major class of antibiotics has increased in recent years due to indiscriminate use of synthetic antimicrobial drugs [7]. In 
addition, high cost and adverse side effects are commonly associated with popular synthetic antibiotics such as hypersensitivity, allergic reactions, immunosuppression and are major burning global issues in treating diseases [8]. Hence, recent attention has been paid to biologically active extracts and compounds from plant species used in herbal medicines [9]. It has been proved effective in the treatment of diseases simultaneously mitigating many of the side effects which are often associated with synthetic antibiotics [10]. Positive response of plant based drugs and less or no side effects might lies in the structure of the natural products which reacts with toxins and/or pathogens in such a way that less harm is done to other important molecules or physiology of host. The flavonoids isolated from Tridax procumbens (TPF) were selected in the present study for evaluation of their anti-bone resorptive activities. The $T$. procumbens is well adapted to the harsh climatic conditions and is well known for their medicinal properties among local natives. Whole plants is made into paste and applied on fresh cuts [11]. In ayurvedic medicine, the TPF is recorded as a hepatic stimulant. The TPF from leaves and root bark are traditionally used for dropsy, anaemia, arthritis, and gout. It is used for the treatment of asthma, ulcer, piles, and urinary problems [12]. The TPF is also used in treating gastric problems, body pain, and rheumatic pains of joints [13, 14 ], however, no data were found regarding the pharmacological and phytochemical evaluation. The aim of the study was to clarify the TPF inhibits on osteoclasts differentiation and bone resorption activities using primary osteoclastic cells. In this study, osteoclast formation was assessed by counting the number of tartrate resistant acid phosphatase (TRAP) positive multinucleated cells and by measuring both TRAP activities. Present results demonstrated that the TPF inhibited osteoclasts differentiation and TRAP activities.

\section{Results \\ Effect of the TPF on osteoclast formation}

To examine the effect of the TPF on osteoclast formation, cultures of the primary osteoclast cells were treated with the TPF at concentrations of 0,50 and $100 \mu \mathrm{g} / \mathrm{ml}$ for 7 days. Greater numbers of TRAP-positive multinucleated osteoclasts were observed in the control group in comparison with the TPF treated groups (Fig. 1a, c). Osteoclasts treated with 50 and $100 \mu \mathrm{g} / \mathrm{ml}$ of the TPF were smaller and exhibited fewer nuclei than osteoclasts of the control group (Fig. 1a, c). Moreover, treatment with $100 \mu \mathrm{g} / \mathrm{ml}$ of the TPF resulted in markedly fewer multinucleated osteoclasts in cultures to compare in the control group. Treatment with $100 \mu \mathrm{g} / \mathrm{ml}$ of the TPF strongly suppressed cell-cell fusion among the primary osteoclast cells (Fig. 1a). The TPF inhibited mature osteoclasts in terms of formation of TRAP-positive multinuclear osteoclasts (Fig. 1a-d). TRAP-positive multinucleated osteoclasts activity and osteoclast surface area were decreased significantly in cultures treated with 50 and $100 \mu \mathrm{g} / \mathrm{ml}$ of the TPF than the control group. Treatment with the TPF reduced the number of mature osteoclasts were dose dependent manner (Fig. 1a).

\section{The TPF inhibited pit formation}

The TPF inhibited RANKL-induced pit formation and dose dependently reduced pit formation in the primary osteoclast cells at concentrations of 50 and $100 \mu \mathrm{g} / \mathrm{ml}$ of the TPF compare to the control group (Fig. $2 \mathrm{a}-\mathrm{c}$ ). The TPF inhibited mature osteoclasts formation and resorption pit were decreased significantly in cultures treated with 50 and $100 \mu \mathrm{g} / \mathrm{ml}$ of the TPF than the control group. Treatment with the TPF reduced the total resorpted area of mature osteoclasts (Fig. 1a-c).

\section{Effect of the TPF on mRNA expression level in the primary osteoclast cells}

Following treatment with the TPF for 7 days, all cells in each well were harvested; subsequently, cells were used to reverse transcribe mRNA directly into cDNA with the Whole Transcriptase Amplification Kit. The Trap, Cathepsin K, Mmp-9 and Mmp-13 mRNA levels per well were significantly lower in the TPF-treated cells than in control cells (Fig. 3b-e). Moreover, the Trap, Cathepsin K, Mmp9 and $M m p-13$ mRNA levels were substantially lower in cells treated with $100 \mu \mathrm{g} / \mathrm{ml}$ of the TPF in comparison with cells treated with $50 \mu \mathrm{g} / \mathrm{ml}$ of the TPF affected The Trap, Cathepsin K, Mmp-9 and Mmp-13 mRNA levels in a dose dependent manner (Fig. 3b-e).

\section{Effect of the TPF on Cathepsin K, MMP-9 and MMP-13 activity}

The primary osteoclast cells culture supernatant samples obtained after 7 days in cultures. The pro-Cathepsin K, pro-MMP-9 and pro-MMP-13 activity was detected in all samples (Fig. 4a-d). The Cathepsin K, MMP-9 and MMP-13 samples were diluted with $\mathrm{ddH}_{2} \mathrm{O}$ prior to measurement of enzymatic activity. Pro-Cathepsin K, pro-MMP-9 and pro-MMP-13 activity were significantly lower in those samples derived from cultures treated with 50 and $100 \mu \mathrm{g} / \mathrm{ml}$ of the TPF than in the samples derived from control cultures (Fig. 4a-d). Moreover, The TPF reduced pro-Cathepsin K, pro-MMP-9 and pro-MMP-13 activity in a dose dependent manner (Fig. $4 \mathrm{a}-\mathrm{d}$ ). The concentration of $100 \mu \mathrm{g} / \mathrm{ml}$ of the TPF appeared to suppress pro-Cathepsin K, pro-MMP-9 and pro-MMP-13 activity to a greater extent than the concentration of $50 \mu \mathrm{g} / \mathrm{ml}$ of the TPF. 


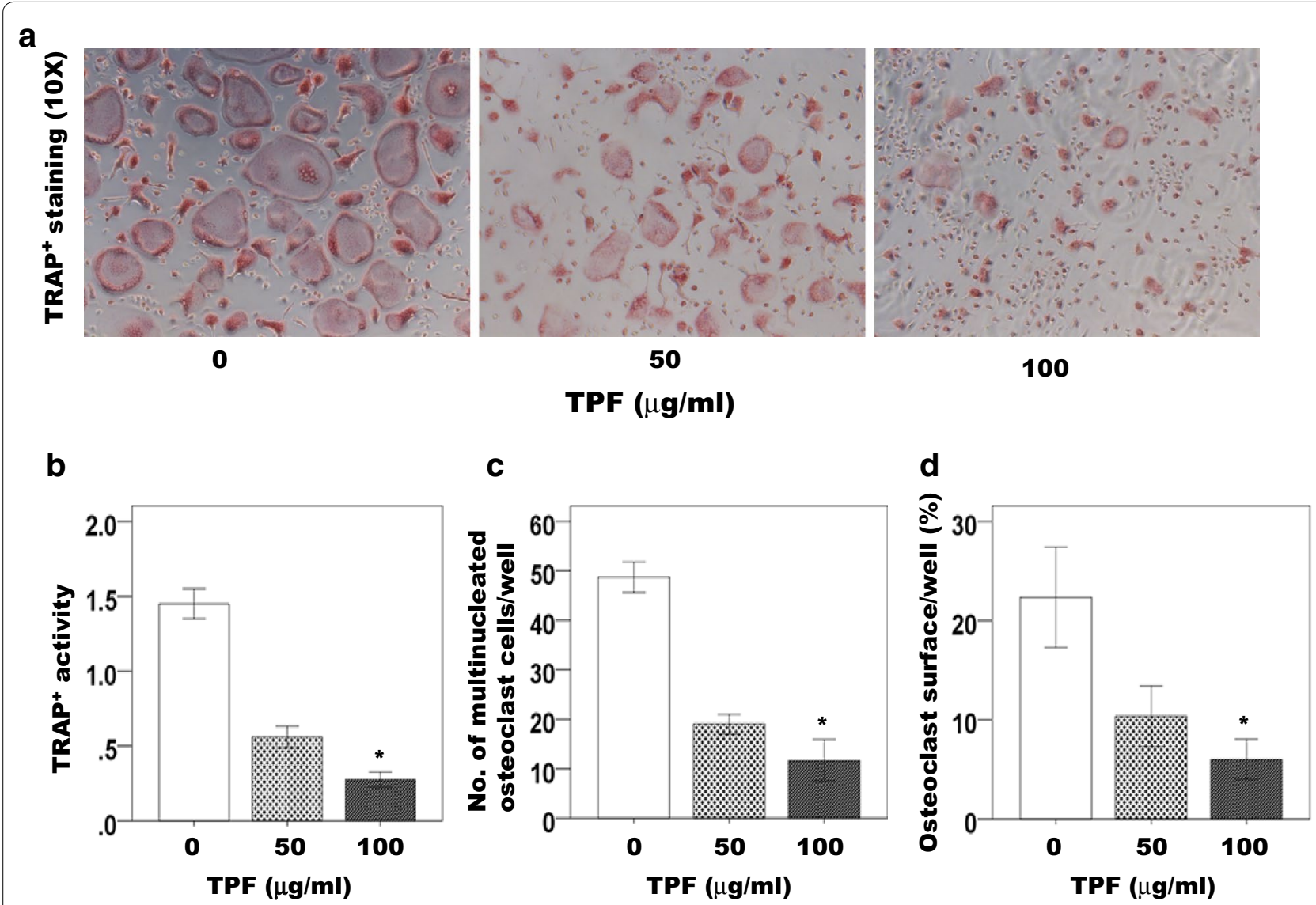

Fig. 1 Effect of the TPF on osteoclast formation in vitro. Cells were cultured with RANKL ( $30 \mathrm{ng} / \mathrm{ml})$ and M-CSF ( $30 \mathrm{ng} / \mathrm{ml})$ for 7 days in the presence of 0,50 or $100 \mu \mathrm{g} / \mathrm{ml}$ of the TPF. Osteoclasts were identified via tartrate-resistant acid phosphatase (TRAP). $\mathbf{a}$ TRAP ${ }^{+}$cells are shown in red and the magnification in $\mathbf{a}$ represent $\times 10, \mathbf{b}$ TRAP $^{+}$multinucleated cells characterized by more than three nuclei were counted, $\mathbf{c}$ osteoclast number/well (N.Oc/well), $\mathbf{d}$ osteoclast surface/well (Oc.S/well). The data were expressed as the mean \pm SD $(n=4)$ for each group. * $p<0.05$

\section{Discussion}

The present study found that the TPF at doses between 50 and $100 \mu \mathrm{g} / \mathrm{ml}$ significantly inhibited RANKL-induced differentiation of osteoclasts in the primary osteoclastic cells. In doses up to $100 \mu \mathrm{g} / \mathrm{ml}$ of the TPF was not toxic to cultured osteoclast cells (data not shown). It had an inhibitory effect on osteoclasts differentiation of primary osteoclast cells (Figs. 1a-d, 2a-c). Traditional medicines play an important role in health services around the globe. The rational design of novel drugs from traditional medicine offers new prospects in modern healthcare $[6,7,15]$. Dietary habits are known to play a role in the prevention of osteoporosis. Some studies investigated that the potential benefits of fruits, vegetables, tea, and herbs on bone metabolism $[15,16]$. It was showed that the consumption of vegetables and fruits inhibited bone resorption in rats better than meat or milk [17]. The meat and milk products commonly believed to be beneficial for bone health [17]. In South Asia, including Bangladesh, India, Pakistan, Nepal and Srilanka, the TPF is made into paste and applied on fresh cuts [11]. Decoctions of the TPF from T. procumbens leaves and root bark have been traditionally used for treatment of dropsy, anaemia, arthritis, and gout, ulcer, piles, and urinary problems [12]. The TPF also used in the treatment for fever, typhoid, cough, and diarrhea, gastric problems, body pain, and rheumatic pains of joints [18-20]. TPF has antimicrobial effects such as antibacterial, antifungal and antiviral [21-23]. Recently, our study showed that the TPF can promote the osteoblasts differentiation and bone formation (data submitted). This study investigated the direct effects of the TPF on RANKL-induced osteoclastogenesis in the primary osteoclast cells. The primary osteoclast cells do not contain any osteoblast or bone marrow stromal cells or cytokines [24-26]. The TPF blocked the function of osteoclasts and inhibited osteoclastogenesis and TRAP activity. This inhibition occurred at the stage of osteoclastogenesis when cell fusion and multinucleated cell formation occurs. However, we did not find cytotoxic or cell cycle arrest in the primary osteoclast cells when treated with the TPF at concentrations between 50 , and $100 \mu \mathrm{g} / \mathrm{ml}$ (data not shown). 

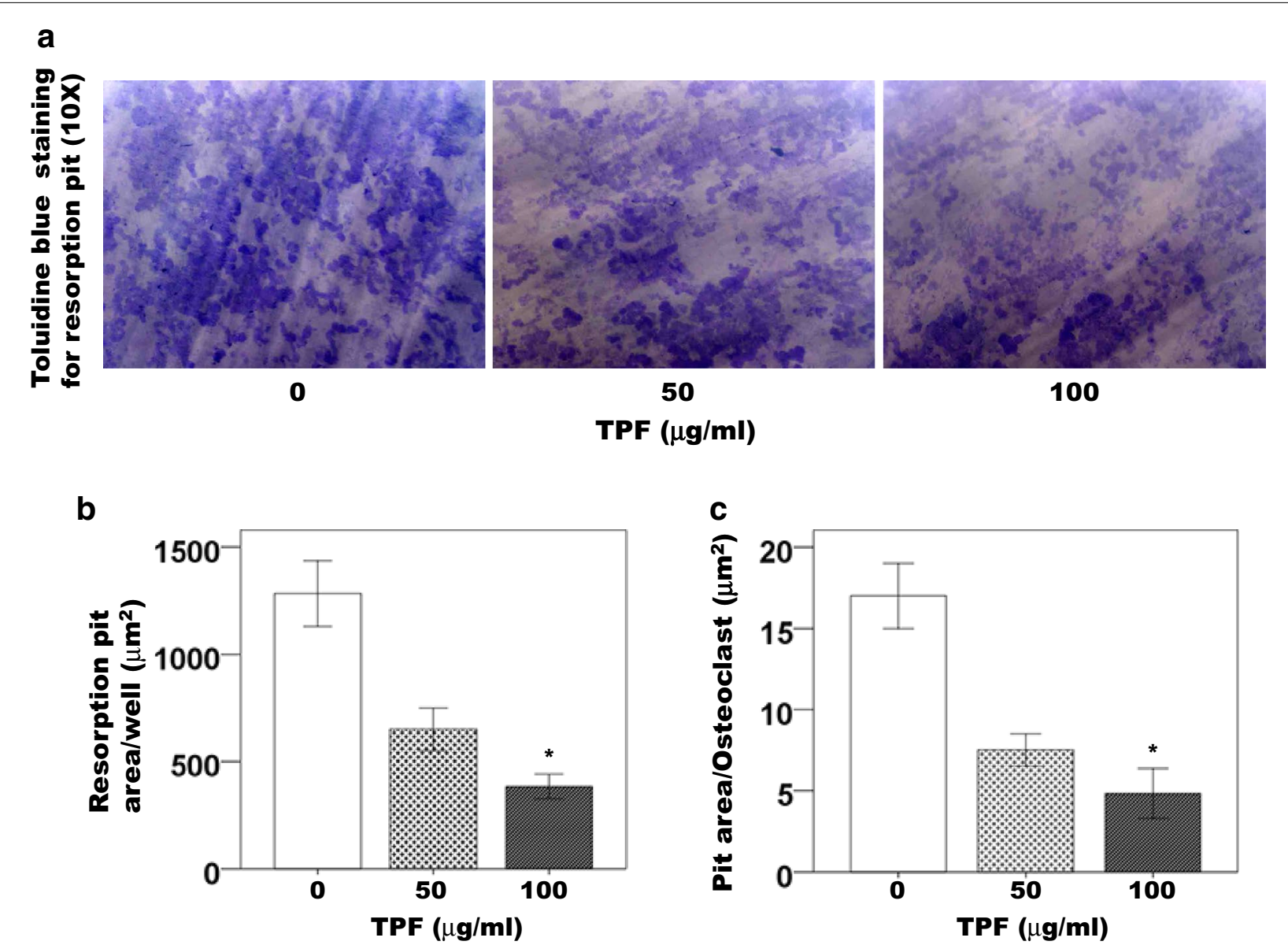

Fig. 2 Effect of the TPF on osteoclast activity as indicated by resorption pit area. Cells were cultured with RANKL ( $30 \mathrm{ng} / \mathrm{ml}) \mathrm{and} \mathrm{M}-\mathrm{CSF}(30 \mathrm{ng} / \mathrm{ml})$ for 7 days in the presence of 0,50 or $100 \mu \mathrm{g} / \mathrm{ml}$ of the TPF and discs were fixed and stained with toluidine blue. a Effects of the TPF on the bone resorbing activity mature osteoclasts and the magnification in $\mathbf{a}$ represent $\times 10, \mathbf{b}$ total resorbed pit area/well and $\mathbf{c}$ resorbed pit area/osteoclasts. The data were expressed as the mean $\pm S D(n=4)$ for each group. ${ }^{*} p<0.05$

Based on the results, the TPF probably blocked osteoclastogenesis by preventing RANKL-mediated activity.

\section{Conclusion}

In summary, this study found that the TPF dose dependently suppressed the osteoclast differentiation in cultured primary osteoclast cells. The regulation of osteoclast differentiation might be an important strategy for the treatment of bone resorption and osteoporosis. The current study demonstrated that the TPF suppress differentiation in primary osteoclast cells. Our results revealed that the TPF may serve as suitable agent in the treatment of bone resorption and osteoporosis.

\section{Methods}

\section{Samples preparation}

Tridax procumbens plant was identified and authenticated by Professor Dr. Anwarul Islam, Department pharmacy, Rajshahi University, Bangladesh. Samples were collected from the northeast part of Bangladesh and stored at the Plant Biotechnology laboratory, Department of Genetic Engineering and Biotechnology, Shahjalal University of Science and Technology, Sylhet-3114, Bangladesh (Serial no. GEB09032014/3). Different parts of $T$. procumbens (root, stem, leaf, and flowers) were separately shade dried, finely powdered using a blender, and subjected to extraction following the method as described elsewhere, with some modifications $[27,28]$.

\section{Reagents}

Penicillin, streptomycin, $\alpha$-MEM, and fetal bovine serum were purchased from Invitrogen (Carlsbad, CA, USA). Recombinant soluble human M-CSF, human RANKL, Recombinant soluble human M-CSF and human RANKL and all other reagents were purchased from SigmaAldrich (St. Louis, MO, USA). 


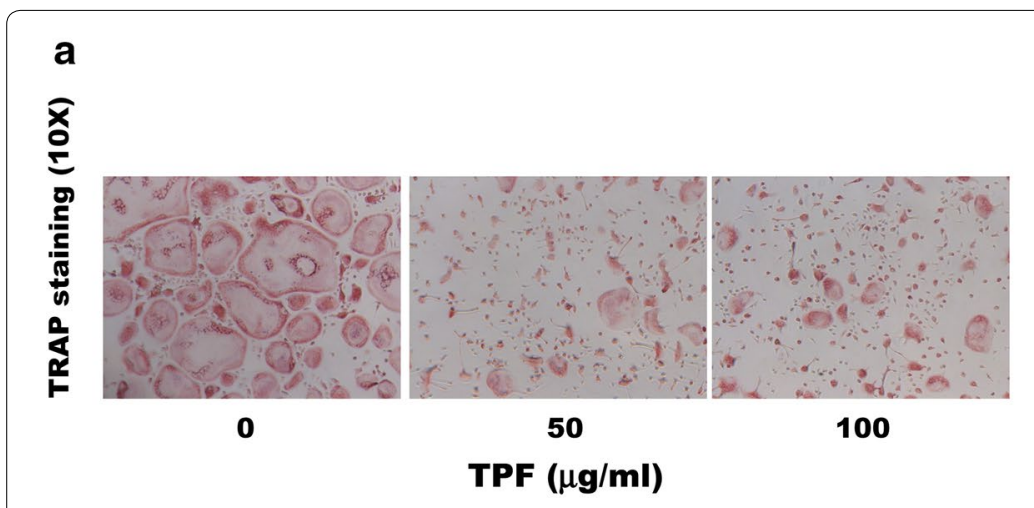

C

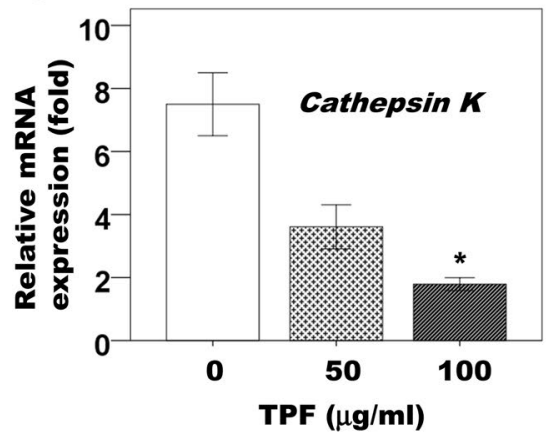

d

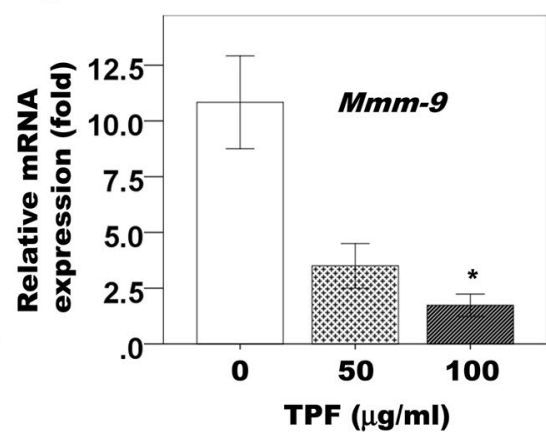

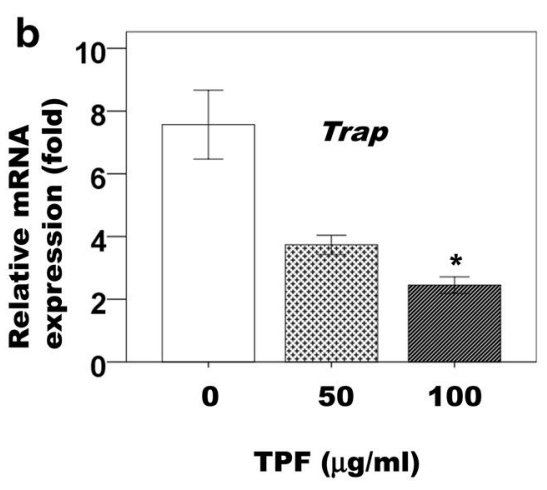

e

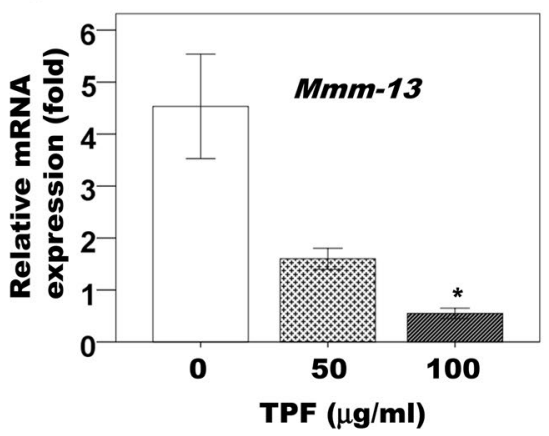

Fig. 3 Effect of the TPF on mRNA expression in primary osteoclast cells. a TRAP ${ }^{+}$cells are shown in red and the magnification in $\mathbf{a}$ represent $\times 10$, b relative mRNA of Trap expression level, c relative mRNA of Cathepsin K expression level, $\mathbf{d}$ relative mRNA of Mmp- 9 expression level and relative mRNA of Mmp-13 expression level. The data were expressed as the mean \pm SD $(n=4)$ for each group. ${ }^{*} p<0.05$

\section{Animals}

C57BL/6 male mice were obtained from ICDDRB (Dhaka, Bangladesh) and maintained in our animal care facilities as described elsewhere [29, 30]. The experimental procedures were reviewed and approved by the Animal Care and Use Committee of Shahjalal University of Science and Technology, Sylhet, Bangladesh.

\section{Osteoclast formation}

For the primary osteoclast cells, 8 weeks old female $\mathrm{C} 57 \mathrm{BL} / 6$ mice were killed by $\mathrm{CO}_{2}$ asphyxia, then the femur and tibia bones were dissected aseptically. The marrow cells were flushed out with $\alpha$-minimum essential medium ( $\alpha$-MEM, Carlsbad, CA, USA). Bone marrow cells $\left(1.5 \times 10^{4}\right.$ cells/well $)$ were cultured in $\alpha$-MEM containing $50 \mathrm{ng} / \mathrm{ml} \mathrm{M-CSF}$ and $50 \mathrm{ng} / \mathrm{ml}$ RANKL. The cells were assigned to three groups as follows 0,50 , and $100 \mu \mathrm{g} / \mathrm{ml}$ the TPF. Media were changed on the fourth day. The TPF was added to the appropriate cultures each of the 5 days. After incubation, the cells underwent TRAP staining using a Tartrate Resistant Acid Phosphatase Kit. We observed the TRAP-positive multinucleated cells (with three or more nuclei) under light microscopy and counted them using image analyzing system (KS400; Carl Zeiss, Jena, Germany).

\section{TRAP activity measurement}

After five days culture of bone marrow-derived osteoclasts with appropriate treatment were lysed and incubated for $1 \mathrm{~h}$ with a reaction buffer containing paranitrophenylphosphate (pNPP). The reaction was stopped with $0.3 \mathrm{~N} \mathrm{NaOH}$ solutions, and optical densities were read and analyzed by microplate spectrophotometer at 405 nm (T60 U, PG Instruments Ltd., England).

\section{Osteoblasts and osteoclasts co-culture}

Eight weeks old female C57BL/6 mice were killed by $\mathrm{CO}_{2}$ asphyxia, then the femur and tibia bones were dissected aseptically. The marrow cells were flushed out with $\alpha$-minimum essential medium. The bones (without marrow) were cut into pieces (less than $1 \mathrm{~mm}$ in diameter), digested with $0.2 \%$ collagenase for $1 \mathrm{~h}$ to harvest the mature osteoblast cells. For the osteoclast co-culture cells model, the cells were seeded into 6-wells plates at a density of osteoblasts $2 \times 105$ cells and bone marrow cells 

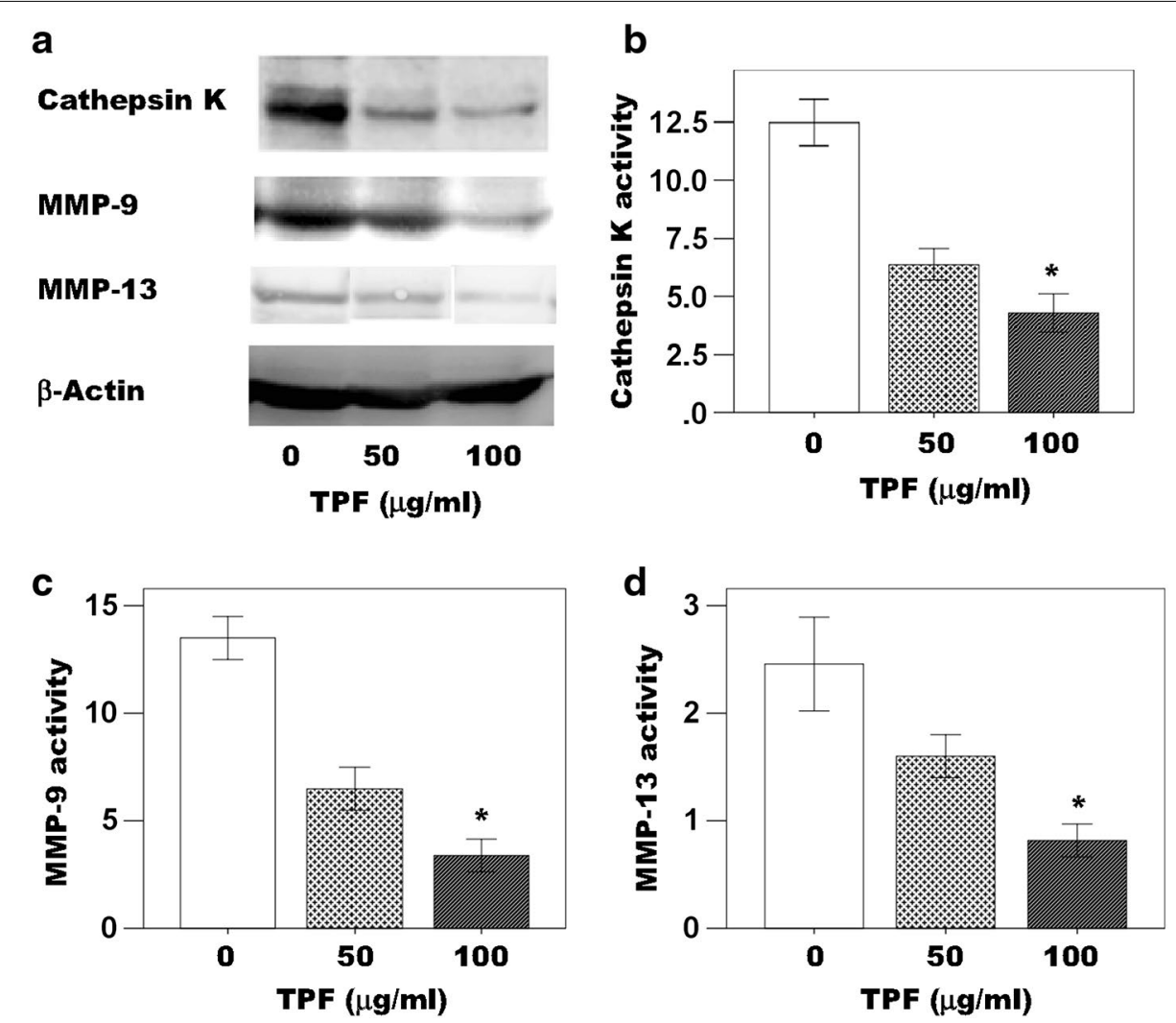

Fig. 4 Effects of the TPF on Cathepsin K, MMP-9, MMP-13 and $\beta$-actin expression in primary osteoclast cells. a The TPF down regulated Cathepsin K, MMP-9 and MMP-13 proteins expression and $\beta$-actin served as the control for the protein assay, $\mathbf{b}$ cathepsin K activity, $\mathbf{c}$ MMP-9 activity and $\mathbf{d}$ MMP13 activity. The data were expressed as the mean $\pm S D(n=4)$ for each group. ${ }^{*} p<0.05$

$1.4 \times 107$ cells/well in $\alpha$-MEM supplemented with $10 \%$ fetal bovine serum, antibiotics $(100 \mathrm{U} / \mathrm{ml}$ of penicillin $\mathrm{G}$ and streptomycin $100 \mathrm{ng} / \mathrm{ml}$ ) in a humidified atmosphere with $5 \% \mathrm{CO}_{2}$ and $95 \%$ air at $37{ }^{\circ} \mathrm{C}$. The cells were assigned to three groups as follows 0,50 , and $100 \mathrm{mg} /$ $\mathrm{ml}$ the TPF. Media were changed on the fourth day. The TPF was added to the appropriate cultures each of the 5 days. After incubation, the cells underwent TRAP staining using a Tartrate Resistant Acid Phosphatase Kit. We observed the TRAP-positive multinucleated cells (with three or more nuclei) under light microscopy and counted them using image analyzing system (KS400; Carl Zeiss, Jena, Germany).

\section{Functional bone resorption assay}

The primary osteoclast cells were cultured with RANKL (50 ng/ml) and M-CSF $(50 \mathrm{ng} / \mathrm{ml})$ for 21 days. Various concentrations of the TPF were added to cultured media to measure osteoclastic cell-mediated mineral resorption. After the culture period, cells were removed using $6 \% \mathrm{NaOCl}$ and $5.2 \% \mathrm{NaCl}$. The resorption area was observed under a light microscope and analyzed by using image analyzing system (KS400; Carl Zeiss, Jena, Germany).

\section{Reverse transcriptase-polymerase chain reaction analysis}

Osteoclasts cells were seeded in 6-well plates for 7 days at $37{ }^{\circ} \mathrm{C}$ in $5 \% \mathrm{CO}_{2}$ in an osteoclast differentiation medium containing $50 \mathrm{ng} / \mathrm{ml} \mathrm{M-CSF}$ and $50 \mathrm{ng} / \mathrm{ml}$ RANKL at a density of $1 \times 10^{6}$ cells/well and cells were treated with the TPF at concentrations of 0,50 , and $100 \mu \mathrm{g} / \mathrm{ml}$. Total RNA from the cells of each well was isolated using NucleoSpin (Macherey-Nagel, Duren, Germany). RNA aliquots were reverse transcribed to complementary DNAs by using an oligo (dT) primer (Roche), deoxynucleotide triphosphate (dNTP), and Moloney murine leukemia virus (M-MuLV) reverse transcriptase (Fermentas, Hanover, MD, USA). The complementary DNA products were subjected to PCR amplification with gene-specific primers for mouse Cathepsin K, Mmp-9, and Mmp-13 (Table 1). Real-time RT-PCR amplification was performed using a Light Cycler System (Roche) with a Platinum SYBR Green qPCR Super Mix UDG kit (Invitrogen, Carlsbad, CA, USA). 
Table 1 Primer sequences of real-time PCR

\begin{tabular}{lll}
\hline Gene & Forward & Reverse \\
\hline TRAP & 5'CGTCTCTGCACAGATT & 3'AAGCGCAAACGGTAG \\
& GCAT & TAAGG \\
Cathepsin K & 5'CGAAAAGAGCCTAGCGA & 3'TGGGTAGCAGCAGAAACA \\
MM9 & 5'GAACCAATCTCACCGA & 3'GCCACCCGAGTGTAACCATA \\
& CAGG & \\
MM13 & 5'GTCTGAGATTTGTAGG & 3'TCATCAAGCTTCTGTCT \\
& CCG & GTGC \\
\hline
\end{tabular}

\section{Statistical analysis}

We used analysis of variance with an F-test, followed by a t-test. $P$ values less than 0.05 were considered significant. The data are presented as mean \pm standard deviation values of independent replicates.

\section{Authors' contributions}

MAAM was project supervisor, designed of the study, conducted experimental work on biological and animals, choice of assay methods and critically reviewed the manuscript and proof read. MJA, MMA and MAAB carried out experimental work on biological investigation and prepared the initial draft of the manuscript. AK and $\mathrm{Kl}$ assisted in data analysis and interpretation. All authors read and approved the final manuscript.

\section{Author details}

1 Department of Genetic Engineering and Biotechnology, Shahjalal University of Science and Technology, Sylhet 3114, Bangladesh. ${ }^{2}$ Department of Anthropology, Shahjalal University of Science and Technology, Sylhet 3114 Bangladesh. ${ }^{3}$ Department of Applied Nutrition and Food Technology, Islamic University, Kustia 7003, Bangladesh. ${ }^{4}$ Department of Pharmacy, Rajshahi University, Rajshahi 6205, Bangladesh.

\section{Acknowledgements}

This research work was supported in part by the Shahjalal University of Science and Technology, Sylhet-3114, Bangladesh Research Grant-2014.

\section{Compliance with ethical guidelines}

\section{Competing interests}

The authors declare that they have no competing interests.

Received: 7 June 2015 Accepted: 2 September 2015

Published online: 12 September 2015

\section{References}

1. Boyle WJ, Simonet WS, Lacey DL. Osteoclast differentiation and activation. Nature. 2003:423:337-42.

2. Teitebaum SL. Bone resorption by osteoclasts. Science. 2000;289:1504-8.

3. Cummings SR, Kelsey JL, Nevitt MC, O'Dowd KJ. Epidemiology of osteoporosis and osteoporotic fractures. Epidemiol Rev. 1985;7:178-208.

4. Oshita K, Yamaoka K, Udagawa N, Fukuyo S, Sonomoto K, Maeshima K. Human mesenchymal stem cells inhibit osteoclastogenesis through osteoprotegerin production. Arthritis Rheum. 2011;63:1658-67.

5. Togari A, Arai M. Pharmacological topics of bone metabolism: the physiological function of the sympathetic nervous system in modulating bone resorption. J Pharmacol Sci. 2008;106:542-6.

6. Racio MC, Rios JC, Villar A. A review of some antimicrobial compounds isolated from medicinal plants. Phytother Res. 1989;3:117-25.

7. Karaman L, Sahin F, Gulluce M, Ogutcu H, Sngul M, Adiguzel A. Antimicrobial activity of aqueous and methanol extracts of Juniperus oxycedrus L. J Ethnopharmacol. 2003;85:231-5.
8. Schinor EC, Salvador MJ, Ito IY, Dias DA. Evaluation of the antimicrobial activity of crude extracts and isolated constituents from Chresta scapigera. Braz J Microbiol. 2007;38:145-9.

9. Essawi T, Srour M. Screening of some Palestinian medicinal plants for antibacterial activity. J Ethanopharmacol. 2000;46:343-9.

10. Iwu MW, Duncan AR, Okunji CO. New antimicrobials of plant origin. In Janick J, editor. Perspectives on new crops and new uses. Alexandria: ASHS Press; 1999. p. 457-62.

11. Dhar U, Singh UK, Uddin A. Ethnobotany of Bhuyans and Juangs of Orissa. Med Plants. 2003;7:200.

12. Warrier PK, Nambiar VPK, Ramankutty C. Indian medicinal plants; a compendium of 500 species. Orient Longman. 2003;1:368-72.

13. Udupa AL, Kulkarni DR, Udupa SL. Effect of Tridax procumbens extracts on wound healing. Pharm Biol. 1995;33:37-40.

14. Prabhu W, Nalini G, Chidambaranathan N, Kisan SS. Evaluation of antiinflammatory and analgesic activity of Tridax procumbens Linn. agains formalin, acetic acid and CFA induced pain models. Int J Pharm Pharm Sci. 2011;3:126-30.

15. Nino J, Navaez DM, Mosquera OM, Correa YM. Antibacterial, antifungal and cytotoxic activities of eight Asteraceae and two Rubiaceae plants from Colombian biodiversity. Braz J Microbiol. 2006;37:566-70.

16. Hegarty VM, May HM, Khaw KT. Tea drinking and bone mineral density in older women. Am J Clin Nutr. 2000;71:1003-7.

17. Muhlbauer RC, Li F. Effect of vegetables on bone metabolism. Nature. 1999;401:343-4.

18. Mann A, Gbate M, Nda-Umar A. Medicinal and economic plants of Nupeland. Bida: Jube-Evans Books and Publications. 2003; p. 276.

19. Dhasarathan $P$, Hemalatha $N$, Theriappan P, Ranjitsingh AJA. Antibacterial activities of extracts and their fractions of leaves of Tridax procumbens Linn. Australian. J Biomed Sci. 2011;1:13-7.

20. Ghasemzadeh A, Jaafar HZE, Rahmat AH. Effects of solvent type on phenolics and flavonoids content and antioxidant activities in two varieties of young ginger (Zingiber officinale Roscoe) extracts. J Med Plants Res. 2011;5:1147-54

21. Dhanabalan R, Doss A, Jagadeeswari M, Balachandar S, Kezia E, Parivuguna V, Reena CM, Josephine Vaidheki R, Kalamani K. In vitro phytochemical screening and antibacterial activity of aqueous and methanolic leaf extracts of Tridax procumbens against bovine mastitis isolated Staphylococcus aureus. Ethnobot Leafl. 2008;12:1090-5.

22. Jindal A, Kumar P. In vitro antifungal potential of Tridax procumbens L. against Aspergillus flavus and A. niger. Asian J Pharm Clin Res. 2013;6:123-5

23. Suseela L, Sarsvathy A, Brindha P. Pharmacognostic studies on Tridax procumbens L. (Asteraceae). J Phytol Res. 2002;15:141-7.

24. Palombo EA, Semple SJ. Antibacterial activity of traditional Australian medicinal plants. J Ethnopharmacol. 2001;77:151-7.

25. Suda N, Morita I, Kuroda T, Murota S. Participation of oxidative stress in the process of osteoclast differentiation. Biochim Biophys Acta. 1993;1157:318-23.

26. Hung $\mathrm{SH}$, Yeh $\mathrm{CH}$, Huang $\mathrm{HT}$, Wu P, Ho ML, Chen $\mathrm{CH}$, Wang C, Chao D, Wang GJ. Pioglitazone and dexamethasone induce adipogenesis in D1 bone marrow stromal cell line but not through the peroxisome proliferator-activated receptor-gamma pathway. Life Sci. 2008;82:561-9.

27. Sharma B, Kumar P. Extraction and pharmacological evaluation of some extracts of Tridax procumbens and Capparis deciduas. Int J Appl Res Nat Prod. 2009;1:5-12.

28. Shafaghat A, Salimi F. Extraction and determining of chemical structure of flavonoids in Tanacetum parthenium (L.) schultz. bip. Iran J Sci Islam Azad Univ. 2008;18:39-42

29. Mamun MA, Khan M, Neil A, Matsui M, Tabata Y, Ohya K, Aoki K. Gelatin hydrogel carrier with the W9-peptide elicits synergistic effects on BMP2-induced bone regeneration. J Oral Biosci. 2013;55:217-23.

30. Khan M, Neil A, Soysa N, Mamun MA, Nagano K, Mikami R, Furuya Y, Yasuda H, Ohya K, Aoki K. The local administration of TNF- $\alpha$ and RANKL antagonist peptide promotes BMP-2-induced bone formation. J Oral Biosci. 2013:55:47-54 